\section{OCTOBER 2010}

Controversies and Advances in the Treatment of Cardiovascular Disease: The Tenth in the Series

Controversies and Advances in the Treatment of Cardiovascular Disease: The Tenth in the Series will be held October 7-8, 2010, at the Montage Beverly Hills, Beverly Hills, California. For information, contact: Promedica InternationalCME(E-mail: Jtercheck@ promedicacem.com; Web site: www. promedica.com).

\section{NOVEMBER 2010}

Cardiovascular Tips for the Practitioner: Optimizing Management Techniques and Treatment

Cardiovascular Tips for the Practitioner: Optimizing Management Tech-

\footnotetext{
$\overline{\text { Announcements }}$ of major meetings and other significant activities must be received at least 8 weeks before the desired month of publication. Information will be limited to title of meeting, date, place, and an address to obtain further information. Send announcements to Ryan Walther, Managing Editor, The Journal of Thoracic and Cardiovascular Surgery, 900 Cummings Center, Suite 221-U, Beverly, MA 01915 (E-mail: rwalther@prri.com).
}

niques and Treatment will be held November 5-6, 2010, at The Venetian, Las Vegas, Nevada. For information, contact: Promedica International CME (E-mail: Jtercheck@promedicacem. com; Web site: www.promedica.com).

\section{MARCH 2011}

Interventional Cardiology 2011: 26th Annual International Symposium

Interventional Cardiology 2011: 26th Annual International Symposium will be held March 13-18, 2011, at the Silvertree Hotel, Snowmass Village, Colorado. For information, contact: Promedica International CME (E-mail: rlaw@promedicacem.com; Web site: www.promedica.com).

\section{Society for Cardiothoracic Surgery in Great Britain and Ireland}

The 2011 Annual Meeting and Cardiothoracic Forum Excel will be held March 20-22, 2010, in London, United Kingdom. Further details and abstract submission are online at www.scts.org from September 1,
2010 (closing date is midnight November 5, 2010). For information, contact: sctsadmin@scts.org

The Houston Aortic Symposium: Frontiers in Cardiovascular Disease

The Houston Aortic Symposium: Frontiers in Cardiovascular Disease will be held March 24-26, 2011, at the Westin Oaks Hotel, Houston, Texas. For information, contact: Promedica International CME (E-mail: Jtercheck@promedicacem. com; Web site: www.promedica.com).

\section{MAY 2011}

ACTS 2011: Advanced Cardiac Techniques in Surgery: The Eighth in the Series

ACTS 2011: Advanced Cardiac Techniques in Surgery: The Eighth in the Series will be held May 4-5, 2011, at the Equitable Center \& the Sheridan New York Hotel, New York, New York. For information, contact: Promedica International CME (E-mail: Jtercheck@promedicacem.com; Web site: www.promedica.com). 